\title{
Risk factors for SARS-CoV-2 infection and hospitalisation in children and adolescents in Norway:
} A nationwide population-based study.

\author{
Ketil Størdal ${ }^{1,2,3}$ \\ Paz Lopez-Doriga Ruiz ${ }^{3}$ \\ Margrethe Greve-Isdahl $\left.\right|^{3}$ \\ Pål Surén ${ }^{3}$ \\ Per Kristian Knudsen ${ }^{2}$ \\ Hanne Løvdal Gulseth ${ }^{3}$. \\ German Tapia ${ }^{3}$
}

\section{Affiliations:}

${ }^{1}$ Department of Pediatric Research, University of Oslo, Oslo, Norway

${ }^{2}$ Division of Pediatric and Adolescent Medicine, Oslo University Hospital, Oslo, Norway

${ }^{3}$ Norwegian Institute of Public Health, Oslo, Norway

Correspondence to: Ketil Størdal, MD, PhD, Department of Pediatric Research, University of Oslo, Postbox 4956 Nydalen, NO-0424 Oslo, Norway; email: ketil.stordal@medisin.uio.no; telephone: 0047-48272337:

Orcid ID: 0000-0002-2620-7646

\section{Keywords:}

SARS-CoV-2, covid-19, risk factor, hospitalisation, comorbidity, socioeconomy, country of origin.

Word count: manuscript 3190, abstract 264.

\section{What is already known on this topic}

Hospital admissions rates for covid-19 among children and adolescents are low compared to adults. Admission rates to hospitals and intensive care units for covid-19 have been higher in minority groups and in children and adolescents with chronic comorbidity.

Whether underlying differences in susceptibility for severe disease or the incidence of infections are driving these associations have not been investigated.

\section{What this study adds}

Low family income, crowded housing and household size, and country of origin outside the Nordic countries were associated with increased risk of infection with SARS-CoV-2.

None of these factors, but chronic comorbidities, were associated with the risk of hospital admission among those infected. 


\begin{abstract}
Objective: To determine risk factors for SARS-CoV-2 infection and hospitalisation among children and adolescents.
\end{abstract}

Design: Nationwide, population-based cohort study.

Setting: Norway from 1 March 2020 to 31 April 2021.

Participants: All Norwegian residents $<18$ years of age.

Main outcome measures: Population-based health care and population registries were used to study risk factors for SARS-CoV-2 infection, including socioeconomic factors, country of origin, and preexisting chronic comorbidities. All residents were followed until age 18 , emigration, death, or end of follow-up. Hazard ratios (HR) estimated by Cox regression models were adjusted for testing frequency. Further, risk factors for admission to the hospital among the infected were investigated.

Results: Of 1182796 residents, 22608 (1.9\%) tested positive by polymerase chain reaction or lateral flow tests, of whom 107 (0.5\%) were admitted to a hospital. Low family income (aHR 1.40, 95\% confidence interval 1.36 to 1.46$)$, crowded housing (1.35, 1.30 to 1.39 ), household size, age, and area of living were independent risk factors for infection. A non-Nordic country of origin was the strongest risk factor (aHR 2.37, 95\% Cl 2.30 to 2.49 ), whereas chronic comorbidity was not associated with the risk of infection. Chronic comorbidity was associated with hospitalisation (aHR 4.15, 2.63 to 6.56), in addition to age, whereas socioeconomic status and country of origin did not predict hospitalisation among those infected.

Conclusions: Socioeconomic factors, country of origin, and area of living were associated with the risk of SARS-CoV-2 infection. However, these factors did not predict hospitalisation among those infected. Chronic comorbidity was associated with the risk of admission but not with the overall risk of acquiring SARS-CoV-2. 


\section{Introduction}

The risk of severe covid-19 increases with age, as shown by the proportion of hospitalisation and death by age categories. ${ }^{1} \mathrm{~A}$ lower prevalence of antibodies in young children demonstrated in serology studies suggests that not only the risk of severe disease but also the risk of infection is lower in the youngest age groups. ${ }^{2-4}$

Exposure to infected household members is the primary source of infection, ${ }^{5}$ in addition to exposure from other contacts, including peers in day-care/school and leisure activities. ${ }^{6}$ Little is known regarding socioeconomic risk factors, such as household crowding, household size, and family income, for infection in children and adolescents. ${ }^{5}$ Country of origin has been associated with an increased risk of hospitalisation, but it is unclear whether this is related to socioeconomic factors or increased susceptibility to the virus. ${ }^{7-10}$

Chronic conditions that affect children may increase the risk of infection due to exposure through health and care services, particularly for children living in special care with many close adult contacts. Chronic conditions may also increase the severity of covid-19. In a European multicentre study, 25\% of those included in a predominantly hospital-based sample had underlying medical conditions. ${ }^{11}$ Chronic conditions were associated with an increased risk of admission to an intensive care unit (ICU). In the United States, the prevalence of complex morbidity or neuromuscular disease was high among children admitted to ICU care. ${ }^{12}$ However, data on the baseline occurrence of these conditions in the general child population were not available, so the risk for hospitalisation associated with comorbidities could not be determined. A recent systematic review summarised the findings regarding comorbidities in severe covid- $19,{ }^{13}$ but studies tend to capture emergency hospital visits and inpatients and lack data on the vast majority who are infected without hospital encounters. Improved knowledge of the risk factors for infection and hospitalisation is relevant for mitigation and future vaccine strategies.

In this nationwide study covering the first 14 months of the pandemic, the aim was to determine risk factors for covid-19 in the population $<18$ years and to study risk factors for hospitalisation in those infected with SARS-CoV-2. 


\section{Material and methods}

We investigated the epidemiology of SARS-CoV-2 infections in a nationwide, population-based study. In an open cohort, inhabitants $<18$ years living in Norway at any time from $1^{\text {st }}$ March 2020 to $30^{\text {th }}$ April 2021 were included. The end of follow-up was $30^{\text {th }}$ April 2021, age 18 years, or death, whichever occurred first.

Individual-level data was available from the BEREDT C19 registry, developed specifically for emergency preparedness to provide knowledge on the spread of the SARS-CoV-2 virus. ${ }^{14}$ In the registry, the unique national identification number given to all citizens upon birth or immigration was used to link vital sources of information (Fig. 1):

- The National Population Registry includes information on date of birth, sex, municipality, and geographical region (South-East, West, Central, North).

- Statistics Norway (SSB) provides data on socioeconomic factors: household size, household crowding, family income, and country of origin.

- The Norwegian Patient Registry (NPR) is an administrative database that contains data on the activity at all publicly funded hospitals and clinics, including International Classification of Diseases (ICD-10) codes. Reporting to the NPR is mandatory and forms the basis for government reimbursements to specialist health services. The list of ICD-10 codes and their groups that were relevant for this study are provided in Fig. 2.

- The Norwegian Registry for Primary Health Care (NRPHC) covers claims for reimbursement from primary health service providers to the state. For this study, the International Classification for Primary Care (ICPC-2) code for asthma (R96) was used to capture milder forms of asthma not receiving specialist care. The other chronic conditions in our study were cared for at the specialist level; thus, further ICPC-2 codes were not used.

- The Norwegian Surveillance System for Communicable Diseases (MSIS) includes results of all positive and negative polymerase chain reaction (PCR) tests and rapid antigen tests for SARSCoV-2. The dates of testing and test results are legally required to be reported from all laboratories to the MSIS. Some negative results could be missing before $1^{\text {st }}$ April 2020, but all positive results are included. Serology results were not available, except for in suspected cases of multisystem inflammatory syndrome (MIS-C).

An institutional review board was conducted. The Regional Ethics Committee of South-East Norway confirmed ( $4^{\text {th }}$ June $2020, \# 153204$ ) that an external ethical review board was not required for the use of BEREDT C19. 
medRxiv preprint doi: https://doi.org/10.1101/2021.07.01.21259887; this version posted July 5, 2021. The copyright holder for this preprint (which was not certified by peer review) is the author/funder, who has granted medRxiv a license to display the preprint in perpetuity.

It is made available under a CC-BY-NC-ND 4.0 International license .

\section{Main outcomes:}

The main outcome was any infection by SARS-CoV-2, as confirmed by a PCR test or lateral flow (rapid test). To capture severe covid-19, hospitalisation (admission $>5$ hour duration) with a primary or secondary diagnosis of covid-19 (U07.1) and/or MIS-C (U10) was used. ICD-10 codes for admission with covid-19 were extracted to classify the main presentation (MIS-C, respiratory, gastrointestinal, other symptoms, and non-related diagnoses).

\section{Exposures:}

To characterise risk factors for infection and hospitalisation, we included sex and age (at time of a positive test, or at study entry) categorised into age groups (Table 1). The region of living (South-East vs West/Central/North) and size of the municipality $(</ \geq 50,000$ residents) were further studied. Low family income was defined according to official statistics as $<60 \%$ of the median income for Norway (last three years) for the family, weighted by the number of family members. Household crowding was defined by Statistics Norway as having fewer than one living room and $<20 \mathrm{~m}^{2}$ of living space per household member. The size of the household was categorised as shown in Table 1. To study the potential impact of country of origin, we classified by the individuals', maternal/paternal, and grandparents' country of birth. Chronic comorbidities were grouped according to diagnostic codes, as shown in Fig. 2.

\section{Statistics:}

We performed summary statistics for categorical variables, summarising absolute numbers and percentages. Cox regression models were further used to estimate hazard ratios (HRs) for confirmed infection or hospitalisation before the end of follow-up. Proportional hazards were assessed by loglog plots of survival. In the main analysis, we included the aforementioned sets of $a$ priori selected covariates in multivariable models. To account for differences in testing practices and policies, the frequency of testing was adjusted for, with a maximum of one test recorded per week to account for clustered tests due to outbreak investigations.

The frequency of hospitalisation was low among those who were infected. In the analysis of hospitalisation risk, we dichotomized the country of origin and chronic comorbidities. We further explored hospitalisation for primary infection and with MIS-C separately to assess whether comorbidities were risk factors specific to these outcomes. In pre-planned sensitivity analyses, we stratified our analyses for 2020 vs. 2021 because of the introduction of the alpha virus variant in January 2021 and increased test activity in 2021, which may have impacted detection rates. Analyses were further stratified by counties which had a higher spread of infection (Oslo and the surrounding county Viken) compared to the nine other counties in Norway. 
medRxiv preprint doi: https://doi.org/10.1101/2021.07.01.21259887; this version posted July 5, 2021. The copyright holder for this preprint (which was not certified by peer review) is the author/funder, who has granted medRxiv a license to display the preprint in perpetuity. It is made available under a CC-BY-NC-ND 4.0 International license.

\section{Patient and public involvement}

Patients were not involved in setting the research question or the outcome measures. No patients were asked to advise on interpretation or writing up of results. We will disseminate the results of the research to the general public. 
medRxiv preprint doi: https://doi.org/10.1101/2021.07.01.21259887; this version posted July 5, 2021. The copyright holder for this preprint (which was not certified by peer review) is the author/funder, who has granted medRxiv a license to display the preprint in perpetuity.

It is made available under a CC-BY-NC-ND 4.0 International license .

\section{Results}

During the observation period of 14 months, 22608 of 1182796 inhabitants $<18$ years had a positive test for SARS-CoV-2, yielding a cumulative incidence of 19.1/1000 (Table 1). The incidence increased by age category but did not differ by sex (Fig. 3). After adjustments, the risk of infection remained higher from 12-17 years compared to the reference category of $\leq 5$ year (Table 1 ). Of those infected, 107/22608 (4.7/1000) were admitted to a hospital. MIS-C was recorded in 22, yielding an incidence of 1.0/1000 in those with known infection. Of the remaining 85 subjects who were hospitalised, 32 had respiratory codes, seven had gastroenterological and seven respiratory/gastroenterological codes, and 20 had other symptom codes. Nineteen were admitted for reasons other than covid-19, of whom five were infected from birth. The median hospital stay length was two days, and $89 \%$ were discharged within 7 days. Admission to intensive care $(n=11)$ and death $(n=2)$ were rare events, and these outcomes were not studied further.

\section{Socioeconomic and demographic risk factors for infection}

The incidence of infection was highest in the South-East region, and those living in municipalities with $>50000$ inhabitants had a significantly higher risk compared with smaller municipalities (adjusted HR [aHR] 1.43, 95\% Cl 1.39 to 1.48 , Table 1). Living in households with $\geq 4$ members compared with smaller households was associated with an increased risk, and particularly increased with $\geq 6$ in the household (aHR $1.78,95 \% \mathrm{Cl} 1.66$ to 1.90 , Table 1 ). Household crowding and low family income were independent and significant predictors for the risk of infection $(p<0.001$, Table 1).

Country origin outside Nordic countries was associated with an increased risk (aHR 2.37, 95\% $\mathrm{Cl} 2.30$ to 2.49). The risk estimates were highest for residents with family backgrounds from Africa, Asia, and the Middle East/North Africa, whereas the estimates for North America/Oceania were similar as those observed for Nordic countries (Table 1). Age category, region of living and municipality size, low income, household crowding and size, and country of origin were independent predictors for infection with SARS-CoV-2 in the adjusted model (Table 1).

\section{Chronic conditions as risk factors for infection}

Of the total population, 103362 (8.7\%) had diagnoses of chronic conditions, as listed in Fig. 2.

Overall, there was a slightly lower risk of being infected with SARS-CoV-2 in children and adolescents with chronic conditions (aHR $0.93,95 \% \mathrm{Cl} 0.89$ to 0.98 , Fig. 2). None of the groups of chronic comorbidities had a significantly increased risk in unadjusted or adjusted analyses (Fig. 2). Notably, 
we found a significantly lower risk of infection for those with cancer and the prevalent immunemediated conditions of asthma and coeliac disease (Fig. 2).

\section{Risk factors for hospitalisation}

Among those infected with SARS-CoV-2, the risk of hospitalisation was lowest for the age group 6-11 years (Table 2). Sociodemographic factors were not associated with the risk of hospital admission. A non-Nordic country of origin was not a risk factor for hospitalisation among those infected (aHR 1.42, $95 \% \mathrm{Cl} 0.85$ to 2.35 , Table 2). Among those admitted to a hospital, 27 of $107(25 \%)$ had a chronic comorbidity, which was a strong risk factor for hospital admission (aHR $4.15,95 \% \mathrm{Cl} 2.63$ to 6.56 ). Asthma and other chronic cardiopulmonary conditions were the most prevalent, and the latter group was particularly associated with hospitalisation (Table 2). When excluding those admitted with a diagnosis of MIS-C or admission unrelated to covid-19, the risk estimates for chronic comorbidities were not substantially changed (aHR $4.47,95 \% \mathrm{Cl} 2.51$ to 7.95 ). Chronic comorbidity was also associated with increased risk of MIS-C (aHR $3.58,95 \% \mathrm{Cl} 1.31$ to 9.80 ).

Stratified analyses for risk factors for infection by time period showed a difference for age categories, with an increased risk in age groups 6-11 and 12-17 in the first period which was not present in the last period (supplementary Table 1). Analyses stratified by geographical area did not indicate substantial differences between Oslo/Viken vs. other counties (supplementary Table 2). 
medRxiv preprint doi: https://doi.org/10.1101/2021.07.01.21259887; this version posted July 5, 2021. The copyright holder for this preprint (which was not certified by peer review) is the author/funder, who has granted medRxiv a license to display the preprint in perpetuity.

It is made available under a CC-BY-NC-ND 4.0 International license .

\section{Discussion}

The main risk factors for infection with SARS-CoV-2 among children and adolescents in the present study were socioeconomic determinants and country of origin, in addition to geographic region and municipality size. Hospitalisation for covid-19 was very uncommon, but premorbid chronic conditions and young age were associated with increased risk. The country of origin and socioeconomic factors were not associated with the risk for hospitalisation among those infected.

\section{Strengths and limitations of study}

Among several strengths of the current study, sample size provided by the linkage of nationwide registers and avoidance of a selection bias, which is often encountered in hospital-based studies, are prominent. To the best of our knowledge, this is the first large study to determine socioeconomic characteristics and country of origin as risk factors of SARS-CoV2-infection across the range of severity in children and adolescents. The coverage of this nationwide study was high, likely capturing the majority of all infected, as suggested by seroprevalence studies indicating that the majority of cases in our country were detected by PCR. ${ }^{15}$ However, the availability of testing was limited during the first months of the pandemic. This may have resulted in a higher proportion of undetected cases during the first period, particularly among children and adolescents.

Furthermore, the linkage to national diagnosis registers provides trustable detection of relevant chronic comorbidities. A recording of overweight/obesity was not available, and this factor has also been associated with covid-19 severity in children and adolescents. ${ }^{9,10,13}$ Risk factors for disease severity may be biased if chronic disease were part of the test criteria, which to some extent occurred during the early phases of the pandemic. Comorbidity and young age would likely lower the threshold for hospital admission, potentially inflating the observed associations.

Country of origin was the strongest predictor for the risk of infection. Notably, these risk estimates remained highly significant when adjusting for socioeconomic factors. This suggests that country of origin and socioeconomic status were independent factors for the distribution of SARS-CoV-2 in our population. A report from the US showed a higher risk of infection in non-white ethnic groups, but did not account for socioeconomic factors. ${ }^{16}$ How such factors confound associations with country of origin in societies with welfare systems that are different from the publicly funded health care system in Scandinavia should be studied further.

The higher rates of SARS-CoV-2 in non-Nordic groups has also been observed for adults in Norway. ${ }^{17}$ Because family contacts are the main source of infection, a similar difference by country of origin is expected among children and adolescents. Factors related to a higher prevalence in these families are higher occupational exposure and contact with high-endemic areas by travel or visitors. 
medRxiv preprint doi: https://doi.org/10.1101/2021.07.01.21259887; this version posted July 5, 2021. The copyright holder for this preprint (which was not certified by peer review) is the author/funder, who has granted medRxiv a license to display the preprint in perpetuity.

It is made available under a CC-BY-NC-ND 4.0 International license .

Communication of the implemented strict infection control measures may not reach certain groups, and cultural differences in interpersonal contact may increase the vulnerability to infectious diseases.

\section{Comparison with other studies}

Country of origin was not a risk factor for hospitalisation in our study. This is important, as other studies have also raised concern for such an association in children, and this finding was in contrast to most previous studies among hospital-based cohorts of children and adolescents. ${ }^{7-10}$ However, these studies did not provide data that separated the risk of infection from hospitalisation. The current data suggests that a skewed distribution of country of origin among hospitalised children was driven by differences in the spread of infection in society and not by susceptibility to severe disease, in line with a recent US study on risk factors for severe covid-19. ${ }^{18}$ In adults, genetic susceptibility clearly influences the severity of covid-19 infection, ${ }^{19,20}$ which is attributed to gene variants that are differentially distributed across ethnic groups. ${ }^{21}$ Such a genetic susceptibility remains to be proven for severe covid-19 disease among children and adolescents.

The linkage to nationwide registers allowed us to study pre-existing comorbidities as a risk factor for infection and hospital admission. This differs from previous studies reporting whether children and adolescents that were admitted to a hospital with a chronic comorbidity had an increased risk of ICU transfer or death. ${ }^{7-10}$ Because a very low percentage of children and adolescents required admission $(0.47 \%)$, our findings provide new information on risk factors for infection regardless of severity. None of the chronic comorbidities were associated with an increased risk of infection. The national policy during the pandemic was to keep schools and kindergartens open with infection control measures, and only children with severe chronic comorbidities were advised to stay home. However, stricter infection control in vulnerable groups may have led to a somewhat lower risk of infection. Vaccination of adolescents with comorbidities ( $\geq 16$ years age) started in March 2021 and is unlikely to affect our findings because $<700$ had received the vaccine by the end of April 2021.

The excess risk for hospitalisation for children with any comorbidity of HR 4.15 was in line with a large study from the CDC COVID-19-NET, including over 250 centres reporting an adjusted odds ratio (aOR) of 3.55 (95\% Cl 3.14 to 4.01$)^{7}$. However, $88 \%$ in the CDC study were excluded due to missing data, which could bias the associations. Furthermore, chronic comorbidity was a risk factor for hospital admission among 454 children from Colorado (OR 2.73), of whom $15 \%$ were admitted due to symptomatic infection. ${ }^{22}$

Comorbidity was a risk factor for ICU admission or death among hospitalised children and adolescents in a multi-centre study from the first wave in the UK, in which $42 \%$ of hospitalised children had at least one comorbidity and all who died (6/627) had a severe comorbidity. ${ }^{9}$ Similarly, a European study and an American multi-site study found increased risk for ICU admission in those 
with a chronic comorbidity (aOR 3.27 in both studies). ${ }^{11,18} \mathrm{~A}$ complex comorbidity was not a significant risk factor for severity (aOR $1.51,95 \% \mathrm{Cl} 0.51$ to 4.42 ) in a US multi-centre study, although four of seven deaths occurred in such children. ${ }^{10}$ Comorbidities were recorded in $65 \%$ of those with severe, compared to $25 \%$ of non-severe, infections in a large French hospital-based study (aOR 2.9, $95 \% \mathrm{Cl} 0.9$ to 9.9). ${ }^{23}$ MIS-C differed from other admissions characterised by a low occurrence of preexisting comorbidity in the studies of hospitalised cases from the US, UK, and France. ${ }^{9,10,23}$ This contrasts our findings, however our study included few MIS-C cases and should be interpreted cautiously.

Asthma was the most prevalent comorbidity in our study. Children with asthma had a slightly lower risk of infection and a somewhat increased risk of hospital admission compared to children without asthma. Current asthma has been suggested to be negatively associated with the risk of hospitalisation for Covid-19 in children ${ }^{24,25}$ and was not associated with hospitalisation in a study including both children and adults. ${ }^{26}$ Similar to our study, other chronic cardiopulmonary conditions have been reported as risk factors for hospital admission and/or ICU transfer. ${ }^{9,11,23}$ The current study had a limited number of hospitalised children, precluding precise estimates for less frequent comorbidities. Neurological and congenital disorders, malignancy, immunocompromise, and gastrointestinal comorbidities have, to a varying extent, been associated with hospitalisation or ICU admission. ${ }^{11,13,22,23}$

Currently, the vaccine roll-out and discussions about whether children and adolescents should be vaccinated are ongoing. Groups of children and adolescents at risk of a severe course are important to identify, and determinants of a higher risk of infection are relevant if a targeted vaccination strategy is considered. Mitigation strategies in addition to vaccination could also focus on groups with an increased incidence of SARS-CoV-2 or severe complications. Socioeconomic disparities were recently demonstrated in $\mathrm{Brazil}^{27}$ but should be further studied in high-income countries.

Through public health efforts, particularly with testing, contact tracing, quarantine, and isolation, Norway succeeded in limiting the spread of SARS-CoV-2. A lower incidence of SARS-CoV-2 compared to most other countries may reduce the generalisability of our findings.

\section{Conclusion}

The results from the current study provides novel data on the socioeconomic determinants of infection. A strong association with country of origin suggests that non-pharmaceutical and pharmaceutical interventions targeted to minority groups of children and adolescents could mitigate further disease. Chronic comorbidity was associated with the risk of admission but not with the overall risk of acquiring SARS-CoV-2. 


\section{References}

1. Docherty AB, Harrison EM, Green CA, et al. Features of 20133 UK patients in hospital with covid-19 using the ISARIC WHO Clinical Characterisation Protocol: prospective observational cohort study. BMJ. May 22 2020;369:m1985. doi:10.1136/bmj.m1985

2. Pollan M, Perez-Gomez B, Pastor-Barriuso R, et al. Prevalence of SARS-CoV-2 in Spain (ENECOVID): a nationwide, population-based seroepidemiological study. Lancet. Aug 22 2020;396(10250):535-544. doi:10.1016/S0140-6736(20)31483-5

3. Tonshoff B, Muller B, Elling R, et al. Prevalence of SARS-CoV-2 Infection in Children and Their Parents in Southwest Germany. JAMA Pediatr. Jan 22 2021;doi:10.1001/jamapediatrics.2021.0001

4. Viner RM, Mytton OT, Bonell C, et al. Susceptibility to SARS-CoV-2 Infection Among Children and Adolescents Compared With Adults: A Systematic Review and Meta-analysis. JAMA Pediatr. Sep 25 2020;doi:10.1001/jamapediatrics.2020.4573

5. Madewell ZJ, Yang Y, Longini IM, Jr., Halloran ME, Dean NE. Household Transmission of SARSCoV-2: A Systematic Review and Meta-analysis. JAMA Netw Open. Dec 1 2020;3(12):e2031756. doi:10.1001/jamanetworkopen.2020.31756

6. Koh WC, Naing L, Chaw L, et al. What do we know about SARS-CoV-2 transmission? A systematic review and meta-analysis of the secondary attack rate and associated risk factors. PLOS One. 2020;15(10):e0240205. doi:10.1371/journal.pone.0240205

7. Moreira A, Chorath K, Rajasekaran K, Burmeister F, Ahmed M, Moreira A. Demographic predictors of hospitalization and mortality in US children with COVID-19. Eur J Pediatr. Jan 20 2021;doi:10.1007/s00431-021-03955-x

8. Feldstein LR, Tenforde MW, Friedman KG, et al. Characteristics and Outcomes of US Children and Adolescents With Multisystem Inflammatory Syndrome in Children (MIS-C) Compared With Severe Acute COVID-19. JAMA. Feb 24 2021;doi:10.1001/jama.2021.2091

9. Swann OV, Holden KA, Turtle L, et al. Clinical characteristics of children and young people admitted to hospital with covid-19 in United Kingdom: prospective multicentre observational cohort study. BMJ. Aug 27 2020;370:m3249. doi:10.1136/bmj.m3249

10. Fernandes DM, Oliveira CR, Guerguis $S$, et al. Severe Acute Respiratory Syndrome Coronavirus 2 Clinical Syndromes and Predictors of Disease Severity in Hospitalized Children and Youth. J Pediatr. Nov 14 2020;doi:10.1016/j.jpeds.2020.11.016

11. Gotzinger F, Santiago-Garcia B, Noguera-Julian A, et al. COVID-19 in children and adolescents in Europe: a multinational, multicentre cohort study. Lancet Child Adolesc Health. Sep 2020;4(9):653661. doi:10.1016/S2352-4642(20)30177-2

12. Shekerdemian LS, Mahmood NR, Wolfe KK, et al. Characteristics and Outcomes of Children With Coronavirus Disease 2019 (COVID-19) Infection Admitted to US and Canadian Pediatric Intensive Care Units. JAMA Pediatr. Sep 1 2020;174(9):868-873.

doi:10.1001/jamapediatrics.2020.1948

13. Tsankov BK, Allaire JM, Irvine MA, et al. Severe COVID-19 Infection and Pediatric Comorbidities: A Systematic Review and Meta-Analysis. Int J Infect Dis. Feb 2021;103:246-256. doi:10.1016/j.ijid.2020.11.163

14. Health. NIoP. The Norwegian Emergency Preparedness Register (BEREDT C19). . https://www.fhi.no/sv/smittsomme-sykdommer/corona/norsk-beredskapsregister-forcovid-19/ 15. Anda EE, Braaten T, Borch KB, et al. Seroprevalence of antibodies against SARS-CoV-2 virus in the adult Norwegian population, winter 2020/2021: pre-vaccination period. medRxiv.

2021:2021.03.23.21253730. doi:10.1101/2021.03.23.21253730

16. Van Dyke ME, Mendoza MCB, Li W, et al. Racial and Ethnic Disparities in COVID-19 Incidence by Age, Sex, and Period Among Persons Aged $<25$ Years - 16 U.S. Jurisdictions, January 1-December 31, 2020. MMWR Morb Mortal Wkly Rep. Mar 19 2021;70(11):382-388.

doi:10.15585/mmwr.mm7011e1 
medRxiv preprint doi: https://doi.org/10.1101/2021.07.01.21259887; this version posted July 5, 2021. The copyright holder for this preprint (which was not certified by peer review) is the author/funder, who has granted medRxiv a license to display the preprint in perpetuity.

It is made available under a CC-BY-NC-ND 4.0 International license .

17. Indseth T, Grosland M, Arnesen T, et al. COVID-19 among immigrants in Norway, notified infections, related hospitalizations and associated mortality: A register-based study. Scand J Public Health. Feb 2021;49(1):48-56. doi:10.1177/1403494820984026

18. Preston LE, Chevinsky JR, Kompaniyets L, et al. Characteristics and Disease Severity of US Children and Adolescents Diagnosed With COVID-19. JAMA Netw Open. Apr 1 2021;4(4):e215298. doi:10.1001/jamanetworkopen.2021.5298

19. Severe Covid GG, Ellinghaus D, Degenhardt F, et al. Genomewide Association Study of Severe Covid-19 with Respiratory Failure. N Engl J Med. Oct 15 2020;383(16):1522-1534. doi:10.1056/NEJMoa2020283

20. Hu J, Li C, Wang S, Li T, Zhang H. Genetic variants are identified to increase risk of COVID-19 related mortality from UK Biobank data. Hum Genomics. Feb 3 2021;15(1):10. doi:10.1186/s40246021-00306-7

21. Shoily SS, Ahsan T, Fatema K, Sajib AA. Disparities in COVID-19 severities and casualties across ethnic groups around the globe and patterns of ACE2 and PIR variants. Infect Genet Evol. Apr 29 2021:104888. doi:10.1016/j.meegid.2021.104888

22. Graff K, Smith C, Silveira L, et al. Risk Factors for Severe COVID-19 in Children. Pediatr Infect Dis J. Feb 1 2021; doi:10.1097/INF.0000000000003043

23. Ouldali N, Yang DD, Madhi F, et al. Factors Associated With Severe SARS-CoV-2 Infection. Pediatrics. Mar 2021;147(3)doi:10.1542/peds.2020-023432

24. Chatziparasidis G, Kantar A. COVID-19 in Children with Asthma. Lung. Feb 2021;199(1):7-12. doi:10.1007/s00408-021-00419-9

25. Floyd GC, Dudley JW, Xiao R, et al. Prevalence of Asthma in Hospitalized and NonHospitalized Children with COVID-19. J Allergy Clin Immunol Pract. Mar 3 2021;doi:10.1016/j.jaip.2021.02.038

26. Green I, Merzon E, Vinker S, Golan-Cohen A, Magen E. COVID-19 Susceptibility in Bronchial Asthma. J Allergy Clin Immunol Pract. Feb 2021;9(2):684-692 e1. doi:10.1016/j.jaip.2020.11.020

27. Oliveira EA, Colosimo EA, Simoes ESAC, et al. Clinical characteristics and risk factors for death among hospitalised children and adolescents with COVID-19 in Brazil: an analysis of a nationwide database. Lancet Child Adolesc Health. Jun 10 2021;doi:10.1016/S2352-4642(21)00134-6 
medRxiv preprint doi: https://doi.org/10.1101/2021.07.01.21259887; this version posted July 5, 2021. The copyright holder for this preprint (which was not certified by peer review) is the author/funder, who has granted medRxiv a license to display the preprint in perpetuity.

It is made available under a CC-BY-NC-ND 4.0 International license .

\section{Copyright}

The Corresponding Author has the right to grant on behalf of all authors and does grant on behalf of all authors, an exclusive licence (or non-exclusive for government employees) on a worldwide basis to the BMJ Publishing Group Ltd to permit this article (if accepted) to be published in BMJ editions and any other BMJPGL products and sublicenses such use and exploit all subsidiary rights, as set out in our licence.

\section{Contributors}

KS and GT coordinated the study, wrote the analysis plans and had the primary responsibility for writing the paper. GT and PLDR did the statistical analysis and reviewed and commented on drafts. HLG supervised the study, interpreted the data and reviewed and commented on all drafts. MGI, PS and PKK reviewed the drafts and contributed in the interpretation of the findings.

The corresponding author attests that all listed authors meet authorship criteria and that no others meeting the criteria have been omitted.

Funding: No funding received.

Competing interests: All authors have completed the ICMJE uniform disclosure form at www.icmje.org/coi_disclosure.pdf and declare: no support from any organisation for the submitted work; no financial relationships with any organisations that might have an interest in the submitted work in the previous three years; no other relationships or activities that could appear to have influenced the submitted work.

Data sharing: No additional data available.

Transparency: The lead author (KS) affirms that the manuscript is an honest, accurate, and transparent account of the study being reported; that no important aspects of the study have been omitted; and that any discrepancies from the study as planned have been explained. 
medRxiv preprint doi: https://doi.org/10.1101/2021.07.01.21259887; this version posted July 5, 2021. The copyright holder for this preprint (which was not certified by peer review) is the author/funder, who has granted medRxiv a license to display the preprint in perpetuity.

It is made available under a CC-BY-NC-ND 4.0 International license .

Table 1: Characteristics of Norwegian residents $<18$ years infected vs non-infected with SARS-CoV-2 from $1^{\text {st }}$ of March $2020-30^{\text {th }}$ of April 2021.

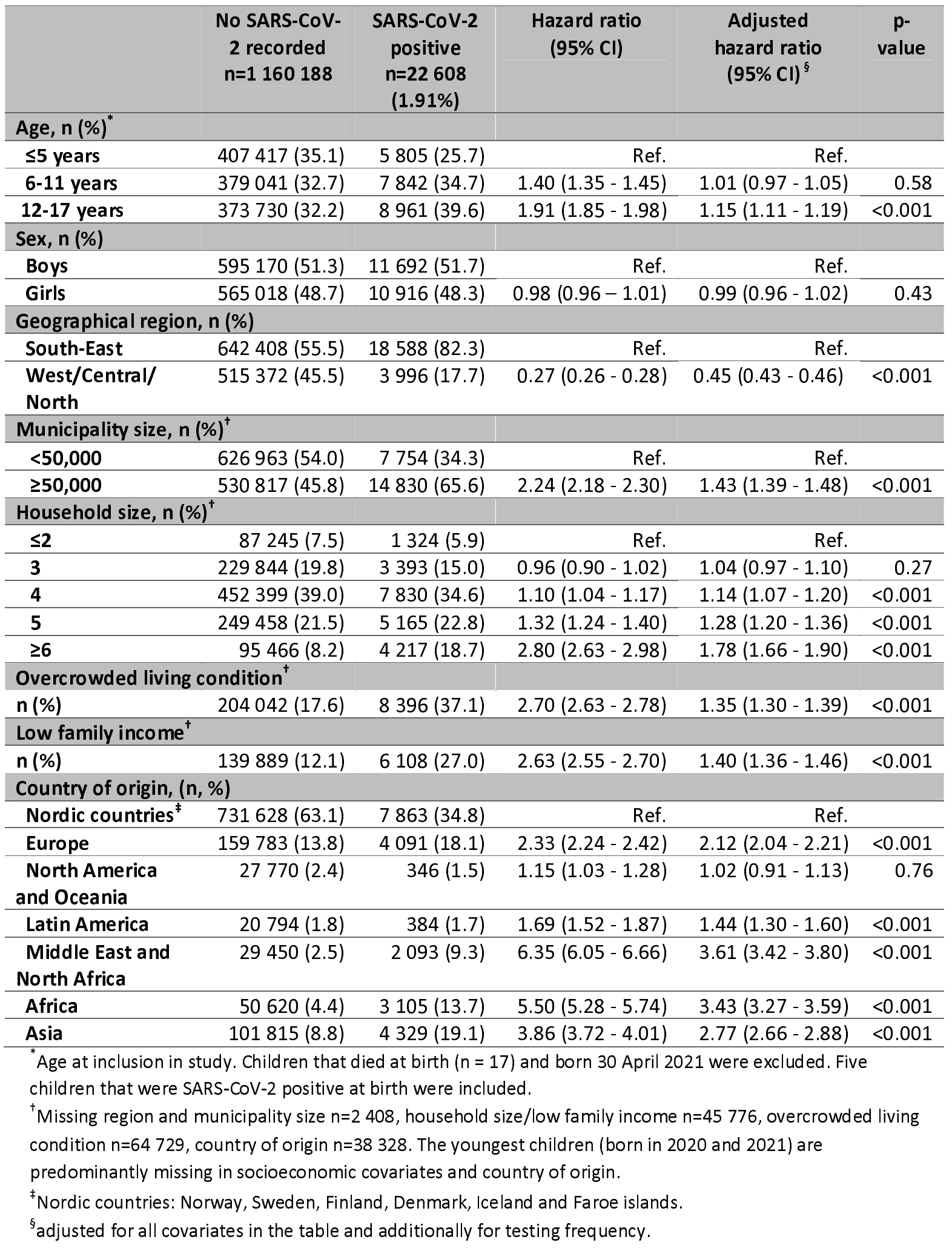


medRxiv preprint doi: https://doi.org/10.1101/2021.07.01.21259887; this version posted July 5, 2021. The copyright holder for this preprint (which was not certified by peer review) is the author/funder, who has granted medRxiv a license to display the preprint in perpetuity.

It is made available under a CC-BY-NC-ND 4.0 International license .

Table 2: Risk for hospital admission among residents $<18$ years infected with SARS-CoV-2 ( $n=22608$ ).

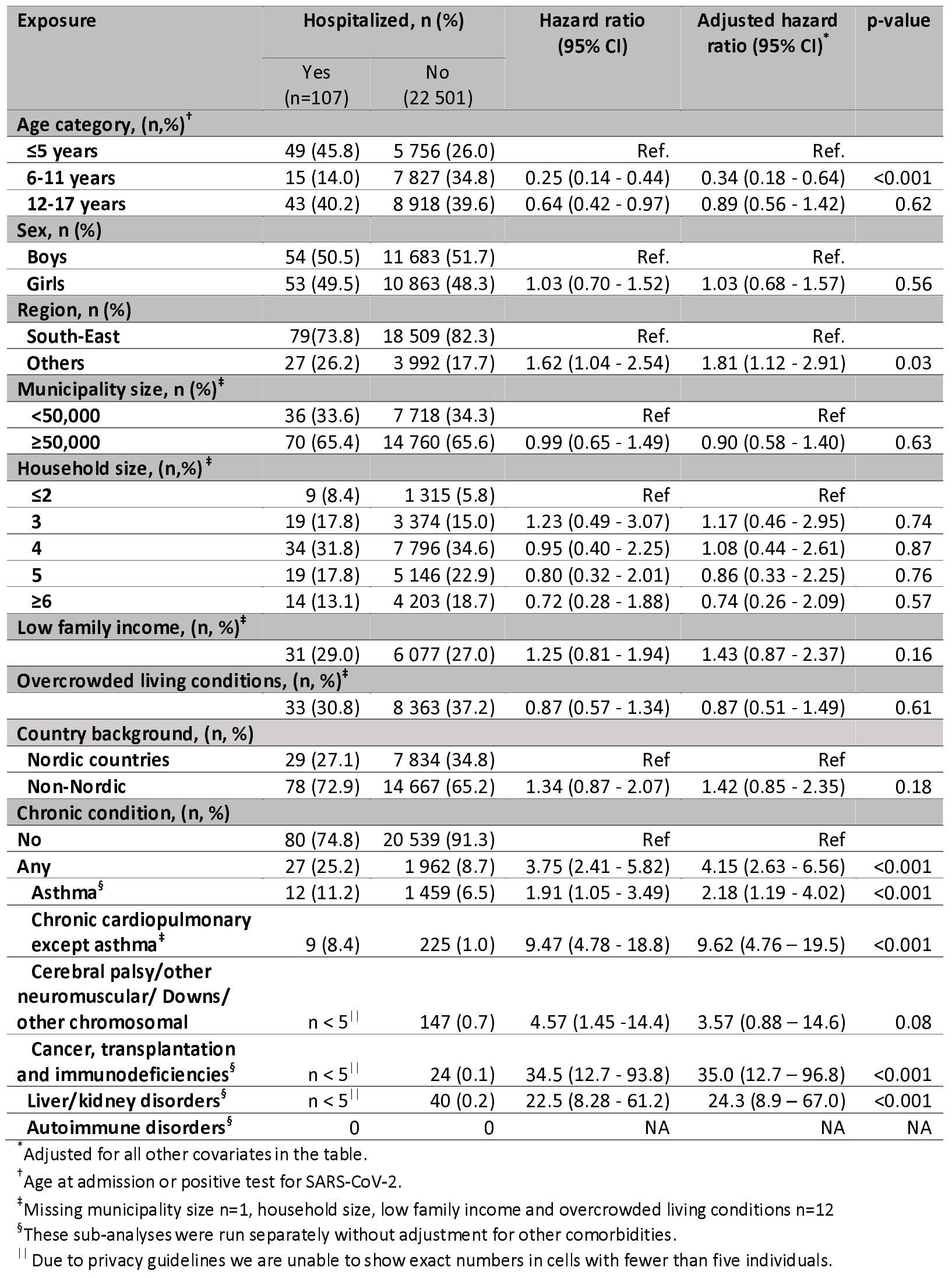


medRxiv preprint doi: https://doi.org/10.1101/2021.07.01.21259887; this version posted July 5, 2021. The copyright holder for this preprint (which was not certified by peer review) is the author/funder, who has granted medRxiv a license to display the preprint in perpetuity.

It is made available under a CC-BY-NC-ND 4.0 International license .

Fig. 1: Flow of data and data sources for BEREDT C19.

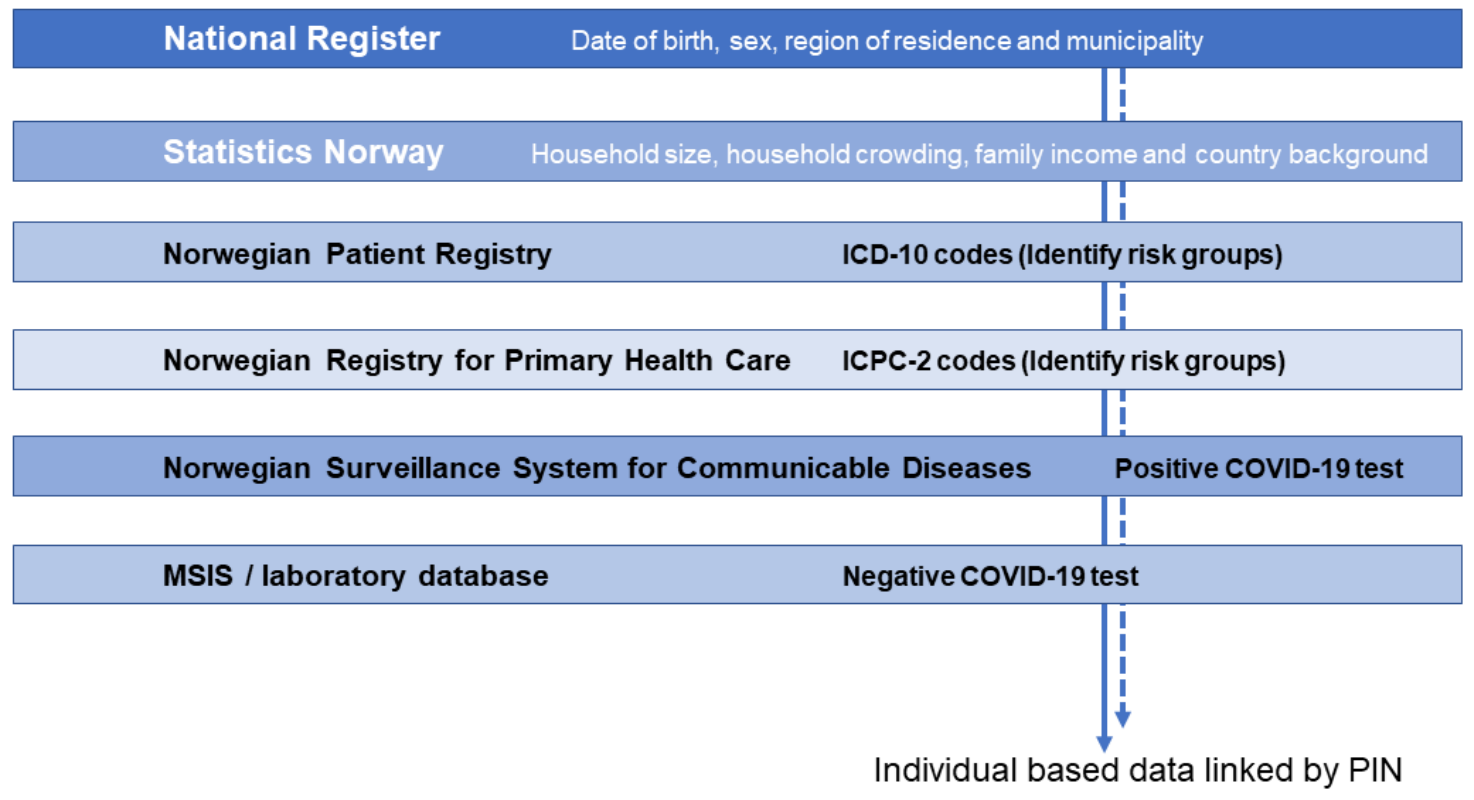


medRxiv preprint doi: https://doi.org/10.1101/2021.07.01.21259887; this version posted July 5, 2021. The copyright holder for this preprint (which was not certified by peer review) is the author/funder, who has granted medRxiv a license to display the preprint in perpetuity.

It is made available under a CC-BY-NC-ND 4.0 International license.

Fig. 2: Pre-existing chronic condition in the population and in those infected with SARS-CoV-2 and adjusted hazard ratio for infection ${ }^{*}$.

\section{Condition}

Cerebral palsy

Any/Other neurological / muscular disorders

G70-G73, Q00-Q04, Q06, Q07

Chromosomal conditions

Downs

Q90

Cancer

Transplantation and Immune disorders

Asthma
J45 R96

Cardial/Pulmonary disease except asthma

Diabetes mellitus

E10-E14

Rheumatological conditions

-Mos

Inflammatory bowel disease

$\mathrm{K} 50, \mathrm{~K} 51, \mathrm{~K} 523$

Celiac disease

K900

Liver/biliary disorders

K754, K73, K74, K758, K760, K830

Kidney disorders
NOO-NO8, N11-N19

Any risk group
Total

2609

1640

2111

1475

1314

945

74817

11601

3885

1493

1358

6104

347

1862

103362
Infected

54

36

43

23

14

14

1471

234

69

27

21

83

9

35

1989
$\operatorname{aHR}(95 \% \mathrm{Cl})$

P-value

$0.95(0.72-1.24) \quad 0.69$

$0.91(0.66-1.27) \quad 0.60$

$0.92(0.68-1.25) \quad 0.59$

$0.69(0.46-1.04) \quad 0.08$

$0.45(0.27-0.76)<0.001$

$0.59(0.35-1.00) \quad 0.05$

$0.94(0.89-0.99) \quad 0.03$

$1.03(0.90-1.18) \quad 0.66$

$0.94(0.74-1.19) \quad 0.62$

$1.18(0.81-1.73) \quad 0.38$

$0.75(0.49-1.15) \quad 0.18$

$0.74(0.60-0.92) \quad 0.01$

$0.81(0.42-1.56) \quad 0.53$

$0.78(0.56-1.10) \quad 0.16$

$0.93(0.89-0.98)<0.001$

*Adjusted for age, sex, region, municipality size, household size, household crowding, low family income, testing frequency and country of origin. 
medRxiv preprint doi: https://doi.org/10.1101/2021.07.01.21259887; this version posted July 5, 2021. The copyright holder for this preprint (which was not certified by peer review) is the author/funder, who has granted medRxiv a license to display the preprint in perpetuity.

It is made available under a CC-BY-NC-ND 4.0 International license .

Fig. 3: Age at time of positive test and sex of infected with SARS-CoV-2 (cumulative cases $1^{\text {st }}$ of March 2020 to $30^{\text {th }}$ of April 2021)

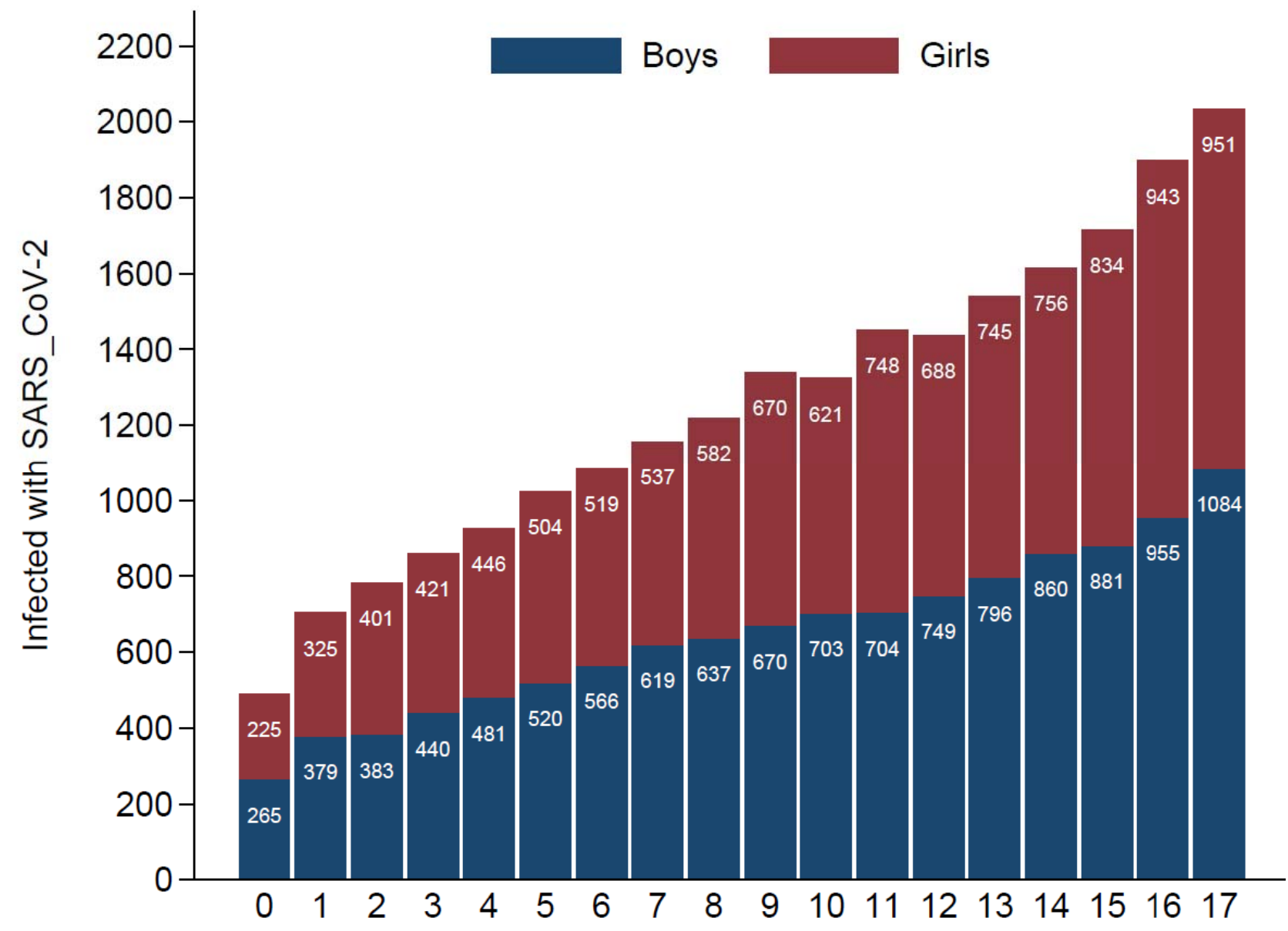

